JGRADASI TEKnIK SIPIL 


\section{JURNAL GRADASI TEKNIK SIPIL POLITEKNIK NEGERI BANJARMASIN}

Jurnal Gradasi Teknik Sipil diterbitkan oleh Pusat Penelitian dan Pengabdian Kepada Masyarakat Politeknik Negeri Banjarmasin. Ruang lingkup makalah meliputi Bidang Teknik dan Manajemen dengan konsentrasi Bidang Transportasi, Geoteknik, Struktur, Keairan dan Manajemen Konstruksi. Isi makalah dapat berupa penyajian isu aktual di bidang Teknik Sipil, review terhadap perkembangan penelitian, pemaparan hasil penelitian, dan pengembangan metode, aplikasi, dan prosedur di bidang Teknik Sipil. Makalah ditulis mengikuti panduan penulisan.

\section{Penanggung Jawab}

Nurmahaludin, ST, MT.

\section{Dewan Redaksi}

Ketua :

Anggota : Riska Hawinuti, ST, MT.

Nurfitriah, S.Pd, MA.

Ir. Rusliansyah, M.Sc.

\section{Reviewer}

Dr. Ir. Yanuar Jarwadi Purwanto, MS. (Institut Pertanian Bogor)

Dr. Ir. Achmad Rusdiansyah, MT. (Universitas Lambung Mangkurat)

Dr. Ir. M. Azhar, M. Sc. (Institut Sains dan Teknologi Nasional)

Dr. Ir. Endang Widjajanti, MT. (Institut Sains dan Teknologi Nasional)

Joni Irawan, ST, MT. (Politeknik Negeri Banjarmasin)

Yusti Yudiawati, ST, MT. (Politeknik Negeri Banjarmasin)

\section{Editing dan Tata Bahasa}

Nurfitriah, S.Pd., MA.

\section{Desain dan Tata Letak}

Abdul Hafizh Ihsani

\section{Alamat Redaksi}

Jurusan Gradasi Teknik Sipil Politeknik Negeri Banjarmasin, Jl. Brigjen H. Hasan Basri 70123 Banjarmasin Telp/Fax 0511-3307757; Email: gradasi.tekniksipil@poliban.ac.id 


\section{JURNAL GRADASI TEKNIK SIPIL}

\section{DAFTAR ISI}

Perencanaan Campuran Lapis Aspal Beton Permukaan Dengan Asbuton Butir Sebagai Filler ...( 1 - 9 )

Surat, Rifanie Gazalie, Pazilatul Mumamiroh

Pengaruh Keberadaan Pasar Sungai Lulut Terhadap Kinerja Jalan Martapura Lama KM. 05 ...( 10 - 19)

\section{Riska Hawinuti}

Analisis Perbandingan Biaya Penggunaan Perancah Kayu Galam Dan Perancah Besi (Scaffolding) ...( $20-32)$ Aunur Rafik, Rinova Firman Cahyani

Tinjauan Debit Andalan untuk Irigasi di Kecamatan Sungai Tabuk Kabupaten Banjar ...( $33-43)$

Fakhrurrazi, Herliyani Farial Agoes, Desi Anggeriyani

Ekosemen Sebagai Media Perekat Pengganti Semen Untuk Beton ...( 44 - 51 ) Marhadi Sastra, Juli Ardita Pribadi R

Pengaruh Posisi, Jumlah Layer Dan Mutu Kayu Terhadap Balok Laminasi Kayu Mahang Dan Kayu Meranti ...( 52 - 60 )

\section{Indriyani Puluhulawa}

Visualisasi Dan Identifikasi Pola Retak Dinding Bata Akibat Penurunan Pondasi Struktur Bangunan Di Kota Banjarmasin ...( 61 - 68 )

\section{Darmansyah Tjitradi, Eliatun}

Pengembangan Perumahan Dengan Desain Konstruksi Dilahan Basah Pada Wilayah Kota Banjarmasin Menggunakan Riset Operasi ...( 69 - 75 )

\section{Eliatun, Darmansyah Tjitradi}




\title{
Ekosemen Sebagai Media Perekat Pengganti Semen Untuk Beton
}

\author{
Juli Ardita Pribadi R.1, Marhadi Sastra2 \\ ${ }^{1,2}$ Dosen Jurusan Teknik Sipil Politeknik Negeri Bengkalis \\ e-mail: *1juliardita@polbeng.ac.id (corresponding author), ${ }^{2}$ marhadi@polbeng.ac.id
}

\begin{abstract}
Abstrak
Sampah merupakan permasalah serius yang dihadapi pada saat ini, banyak pencemaran dan penyakit yang ditimbulkan oleh sampah, oleh sebab itu banyak upaya yang dilakukan supaya sampah bisa di manfaatkan bahkan mengandung nilai ekonomis. Salah satu pemanfaatan sampah adalah sebagai ekosemen yang di jadikan sebagai pengganti semen.

Pada penelitian ini menggunakan mutu beton rencana $f c^{\prime}=10 \mathrm{Mpa}$ dan $f_{c^{\prime}}{ }^{\prime}=20 \mathrm{Mpa}$, pembuatan beton memanfaatkan abu sampah sebagai pengganti semen dalam jumlah yang telah ditentuka, abu sampah diperoleh dari sampah organik dan sampah anorganik yang dibakar sehingga menjadi abu dan kemudian disaring dengan menggunakan saringan 100 dan 200. Variasi penambahan abu 0\%, 10\%, 20\%, 30\%, 40\% dan 50\% dari perbandingan volume. Umur pengujian beton 7, 14 dan 28 hari.

Hasil yang diperoleh dari hasil pengujian, material yang digunakan memenuhi standar yang telah ditentukan, dengan variasi campuran beton berat isi beton tidak berubah.Hasil pengujian kuat tekan beton untuk $f_{c}{ }^{\prime}=10 \mathrm{MPa}$ diperoleh variasi campuran beton yang terbaik adalah 20\% denga kuat tekan sebesar 12,76 MPa pada umur 28 hari, mutu beton yang $f_{c}{ }^{\prime}=20 \mathrm{MPa}$ dengan variasi campuran terbaik $20 \%$ memiliki kuat tekan sebesar 17,29 MPa, nilai kuat tekan terbesar dibanding kuat tekan beton yang mengandung abu, selisih kuat tekan 13,8\% lebih rendah dibandingkan kuat tekan beton normal,sedangkan pengaruh setiap variasi campuran terhadap umur beton adalah semakin lama maka kuat tekannya cenderung meningkat.
\end{abstract}

Kata kunci-eco-cement, concrete, recycle

\section{Abstract}

Waste is a serious problem faced at this time. A lot of pollution and diseases caused by waste, therefore many efforts are made so that waste can be utilized even contain economic value. One of the utilization of waste is as an eco-cement used as a substitute for cement.

This study used the concrete quality of the plan $f c^{\prime}=10 \mathrm{MPa}$ and $\mathrm{fc}^{\prime}=20 \mathrm{MPa}$, the making of concrete utilized waste ash in lieu of cement in predetermined quantities, waste ash obtained from organic waste and inorganic waste that was burned to ash and then filtered using 100 and 200 sieves. Variations of ash addition of $0 \%, 10 \%, 20 \%, 30 \%, 40 \%$ and $50 \%$ of the volume ratio. Age of concrete testing was 7, 14 and 28 days. The results obtained from the test indicate that the material used met a predetermined standard, with the variation of the concrete weight mixture of concrete unchanged. From the concrete strength test result for $f c^{\prime}=10 \mathrm{MPa}$, the best concrete mixed variation is $20 \%$ with compressive strength equal to $12,76 \mathrm{MPa}$ at 28 day age, $\mathrm{fc}=20 \mathrm{MPa}$ concrete quality with best mix variation $20 \%$ has compressive strength of $17.29 \mathrm{MPa}$, the largest compressive strength value compared with the compressive strength of concrete containing ash, the compressive strength difference of $13.8 \%$ lower than the normal compressive strength of the concrete, while the effect of each mixture variation on the age of concrete is linear; with the increase of the age, the compressive strength tends to increase.

Keywords—eco-cement, concrete, recycle 


\section{PENDAHULUAN}

Selama ini permasalahan sampah menjadi masalah yang sangat serius yang dihadapi oleh setiap kota yang ada di Indonesia, hal ini dikarenakan banyaknya tumpukan sampah tanpa adanya kejelasan yang pasti dalam hal pengelolaannya. Umumnya pengolahan yang sering dilakukan adalah dengan proses pembakaran.

Seiring berjalannya waktu pemanfaatan sisa pembakaran sampah terus berkembang, salah satu pemanfaatannya adalah sebagai bahan konstruksi atau sering disebut dengan ekosemen. Penelitian ekosemen diawali pada tahun 1992. Para peneliti Jepang telah mempelajari kemungkinan pemrosesan abu hasil pembakaran sampah dan endapan air untuk dijadikan bahan pembuat semen. Pada hasil penelitian tersebut diketahui bahwa abu hasil pembakaran sampah mengandung unsur yang sama dengan bahan dasar semen pada umumnya. Kebutuhan kandungan $\mathrm{CaO}$ yang masih belum terpenuhi pada abu 'insinerasi' dapat dicukupi dengan penambahan batu kapur. Pada pembuatan ekosemen, klorin dan logam berat yang terkandung pada abu'insinerasi' diekstrak menjadi artificial ore yang kemudian didaur ulang untuk digunakan kembali.

Pemanfaatan dan penelitian tentang ekosemen telah banyak dilakukan tanpa adanya uji coba langsung di lapangan, sehingga penelitian yang berupa suatu kajian eksperimental yang bersifat laboratorium yang berhubungan dengan pemanfaatan abu sampah sebagai bahan dasar penambah dan pengganti semen atau sering dikatakan sebagai ekosemen perlu dilakukan. Berdasarkan latar belakang tersebut maka dilaksanakan penelitian ini yang bertujuan untuk mengetahui berapa nilai kekuatan beton jika menggunakan abu sampah sebagai bahan pengganti dan penambah semen.

\section{Tinjauan Pustaka}

\section{Beton}

Beton adalah suatu komposisi dari beberapa bahan batu-batuan yang direkatkan oleh bahan ikat. Beton dibentuk dari agregat campuran (halus dan kasar) dan ditambah dengan pasta semen. Bahan ini diperoleh dengan mencampurkan dengan agregat halus (pasir), filler, sebagai bahan tambah dengan agregat kasar (kerikil) serta air dan semen dengan perbandingan tertentu berinteraksi secara kimiawi untuk meningkatkan partikel-partikel agregat tersebut menjadi suatu benda padat.

Untuk membuat beton yang baik tidaklah dengan hanya mencampurkan bahan-bahan dasarnya hingga membentukn suatu benda padat, namun perlu diperhatikan juga perhitungan untuk memperoleh adukan beton yang baik dan beton yang dihasilkan juga baik. Beton yang segar dapat dilihat dengan baik terjadinya bleeding (pemisah air dan semen dari adukan) dan segredasi (pemisah kerikil dari adukan) yang dapat menghasilkan beton berkualitas rendah.

\section{Semen}

Semen (cement) adalah hasil industri dari paduan bahan baku: batu kapur/gamping sebagai bahan utama dan lempung/tanah liat atau bahan pengganti lainnya dengan hasil akhir berupa padatan berbentuk bubuk, tanpa memandang proses pembuatannya, yang mengeras atau membatu pada pencampuran dengan air. Semen Portland, merupakan salah satu jenis semen yang sering digunakan untuk membuat bangunan.

Tabel 1.1. Komposisi oksida dan fasa semen Portland

\begin{tabular}{|l|c|l|c|}
\hline $\begin{array}{l}\text { Komposisi } \\
\text { Oksida (\%) }\end{array}$ & & Komposisi Fasa (\%) & \\
\hline $\mathrm{CaO}$ & 63 & $\mathrm{C}_{3} \mathrm{~A}\left(\mathrm{Ca}_{3} \mathrm{Al}_{2} \mathrm{O}_{6}\right)$ & $5-12$ \\
\hline $\mathrm{SiO}_{2}$ & 20 & $\mathrm{C}_{3} \mathrm{~A}\left(\mathrm{Ca}_{3} \mathrm{SiO}_{5}\right)$ & $50-70$ \\
\hline $\mathrm{Al}_{2} \mathrm{O}_{3}$ & 6 & $\beta-\mathrm{C}_{2} \mathrm{~S}_{\left(\mathrm{Ca}_{2} \mathrm{SiO}_{4}\right)}$ & $20-30$ \\
\hline $\mathrm{Fe}_{2} \mathrm{O}_{3}$ & 3 & $\mathrm{C}_{3} \mathrm{AF}\left(\mathrm{Ca}_{3} \mathrm{Al}_{2} \mathrm{Fe}_{2} \mathrm{O}_{10}\right)$ & $5-12$ \\
\hline $\mathrm{SO}_{3}$ & 2 & & \\
\hline $\mathrm{MgO}^{2} \mathrm{O}$ & \\
\hline $\mathrm{K}_{2} \mathrm{O}$ dan $\mathrm{Na}_{2} \mathrm{O}$ & 1 & & \\
\hline Lainnya & 3 & & \\
\hline
\end{tabular}

Sampah Padat Perkotaan (Municipal Solid Waste)

Wirahman (2007) menjelaskan bahwa sampah padat perkotaan (Municipal Solid Waste) dibagi menjadi dua jenis, yaitu organik dan anorganik. Sampah organik adalah sampah yang dapat diurai oleh mikroba misal kertas, kayu, daun, dan lainnya, sedangkan sampah anorganik adalah sampah yang 
tidak dapat diurai oleh mikroba misalnya kaleng, kaca, keramik, dan lainnya.

Sampah yang dapat dimanfaatkan untuk membuat semen yaitu semua jenis sampah kecuali plastik dan logam, terutama jenis sampah organik. Sampah dapat digunakan sebagai bahan dasar pembuatan semen karena sampah menghasilkan abu dan endapan yang mengandung senyawa-senyawa dalam pembentukan semen biasa. Yaitu, senyawasenyawa oksida seperti $\mathrm{CaO}, \mathrm{SiO} 2, \mathrm{Al} 2 \mathrm{O} 3$, dan Fe2O3. Salah satu contoh kandungan abu sampah seperti pada kandungan abu sekam padi dari limbah pertanian.

Tabel 1.2. Persentase kandungan abu sampah dan semen

\begin{tabular}{|l|c|c|c|c|}
\hline Senyawa & $\mathrm{CaO}$ & $\mathrm{SiO}_{2}$ & $\mathrm{AI}_{2} \mathrm{O}_{3}$ & $\mathrm{Fe}_{2} \mathrm{O}_{3}$ \\
\hline Semen Biasa & $62-65$ & $202-25$ & $3-5$ & $3-4$ \\
\hline Abu Insenerasi & $12-31$ & $23-26$ & $13-29$ & $4-7$ \\
\hline
\end{tabular}

Ekosemen

Penelitian tentang ekosemen diawali pada tahun 1992. Beberapa ilmuwan Jepang melakukan penelitian yang didanai oleh Pemerintah Jepang dan dibantu oleh tiga perusahaan semen swasta. Hasil penelitian diketahui bahwa abu hasil pembakaran sampah dapat dijadikan sebagai bahan utama pada pembuatan semen. Perbandingan komposisi pembuatan ekosemen yang senyawa kimianya hampir mirip dengan semen jenis Normal Portland Cement adalah 58,2\% abu sampah, $40 \%$ batu kapur, $0,3 \%$ pasir besi dan 1,3\% tanah liat, dengan pembakaran akhir ekosemen pada suhu $1350 \mathrm{oC}$ (Shimoda dan Yokoyama, 1999).

Penelitian ekosemen juga telah dilakukan dilakukan (Siswati, dkk, 2009) menunjukkan bahwa komposisi terbaik dari ekosemen yaitu 55\% abu sampah organik dan $45 \%$ batu kapur, dengan pembakaran akhir dari ekosemen yaitu pada suhu $900 \mathrm{oC}$. Menghasilkan kuat tekan umur 7 hari sebesar $72,6 \mathrm{~kg} / \mathrm{cm} 2$.

Menurut Susanti Komposisi ekosemen terbaik yaitu $30 \%$ abu sampah organik, $40 \%$ batu kapur dan $20 \%$ tanah liat. Sisanya adalah penambahan gipsum, pasir besi dan Magnesium oksida (MgO). Hasil pengujian kuat tekan umur 28 hari menunjukkan hasil $540,45 \mathrm{~kg} / \mathrm{cm} 2$ untuk kuat patah $81,57 \mathrm{~kg} / \mathrm{cm} 2$
Pemilihan Sampah

Untuk menghasilkan abu sampah yang baik dengan kandungan $\mathrm{CaO}$ dan silika yang tinggi, maka pembakaran sampah harus efektif dan tidak menimbulkan masalah pencemaran lagi. Pembakaran sampah tidak dilakukan dengan cara konvensional, tetapi pembakaran dilakukan dengan menggunakan incenerator. Hal ini disebabkan karena pembakaran sampah secara tradisional menghasilkan gas dioksin yang dapat berbahaya bagi tubuh. Selain itu, pembakaran sampah biasa tidak menghasilkan abu yang berkualitas yang dapat dimanfaatkan untuk membuat semen. Kandungan karbon pada abu hasil pembakaran sampah biasa masih tinggi sehingga akan mengurangi kualitas semen.

Kuat Tekan Beton

Kuat tekan beton adalah besarnya beban persatuan luas yang menyebabkan benda uji beton hancur apabila dibebani dengan gaya tekan tertentu yang dihasilkan oleh mesin tekan (compression machine). Kuat tekan yang dapat dicapai beton tergangtung pada perbandingan air, semen serta tingkat pemadatan. Selain dari pada itu kuat tekan beton di pengaruhi oleh sejumlah faktor oleh perbandingan air semen dan tingkat pemadatannya.

Faktor-faktor yang mempengaruhi dari kuat tekan beton adalah sebagai berikut:

a. Jenis semen dan kualitasnya mempengaruhi kekuatan rata-rata dan kuat batas beton.

b. Jenis dan lekak lekuk bidang permukaan agregat, pada kenyataannya menunjukkan bahwa pengguna agregat akan menghasilkan beton dengan kuat tekan maupun tarik yang lebih dari pada penggunaan kerikil halus dari sungai.

c. Efisiensi dari perawatan (curing). Kehilangan kekuatan sampai sekitar $40 \%$ dapat terjadi jika pengeringan diadakan sebelum waktunya. Perawatan adalah hal yang sangat penting pada pekerjaan lapangan dan pada pembuatan benda uji.

d. Suhu, pada umumnya kecepatan beton bertambah dengan bertambahnya suhu.

Kuat tekan beton dihitung berdasarkan besarnya beban persatuan luas, menurut Persamaan berikut 


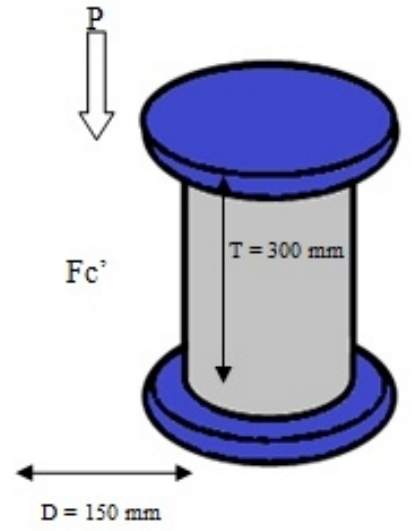

Gambar 1.1. Sketsa pengujian kuat tekan beton

Menghitung Kuat tekan beton dengan rumus :

$A=\frac{1}{4} \times \pi \times D^{2}$

$\mathrm{Fc}^{\prime}=\frac{\mathrm{p}}{\mathrm{A}} \mathrm{MPa}$

Dimana :

$\mathrm{fc}^{\prime}=$ kuat tekan beton (Mpa)

$\mathrm{P}=$ beban maksimum $(\mathrm{N})$

$\mathrm{A}=$ Luas penampang benda uji (mm2)

$\mathrm{D}=$ Diameter benda uji $(\mathrm{mm})$

$\mathrm{T}=$ Panjang benda uji (mm)

Tujuan Penelitian

Adapun tujuan yang ingin dicapai dari penelitan ini adalah sebagai berikut :

1. Mengetahui pengaruh berat isi beton yang menggunakan ekosemen sebagai bahan pengganti semen dengan variasi yang berbeda pada mutu beton $\mathrm{fc}^{\prime}=10 \mathrm{MPa}$.

2. Mengetahui pengaruh berat isi beton yang menggunakan ekosemen sebagai bahan pengganti semen dengan variasi yang berbeda pada mutu beton $\mathrm{fc}^{\prime}=20 \mathrm{MPa}$.

3. Mengetahui pengaruh kuat tekan beton yang menggunakan ekosemen sebagai bahan pengganti semen dengan variasi yang berbeda pada mutu beton $\mathrm{fc}^{\prime}=10 \mathrm{MPa}$.

4. Mengetahui pengaruh kuat tekan beton yang menggunakan ekosemen sebagai bahan pengganti semen dengan variasi yang berbeda pada mutu beton $\mathrm{fc}^{\prime}=20 \mathrm{MPa}$.
Manfaat Penelitian

Adapun manfaat yang ingin dicapai dari penelitan ini adalah sebagai berikut :

1. Dapat mengetahui cara pemanfaatan sampah sebagai bahan pembuat ekosemen.

2. Dapat mengetahui pengaruh penggunaan ekosemen terhadap berat isi beton.

3. Dapat mengetahui pengaruh penggunaan ekosemen terhadap kuat tekan beton.

\section{METODE PENELITIAN}

Adapun lokasi penelitian adalah di Laboratorium Uji Bahan dengan mengumpulkan sampah dari berbagai tempat pembuangan sampah desa Bantan Tua yang berada di kecamatan Bengkalis, Kabupaten Bengkalis. Adapun lokasi pengambilan sampah dan sampel dapat dilihat pada Gambar $1 \mathrm{di}$ bawah.

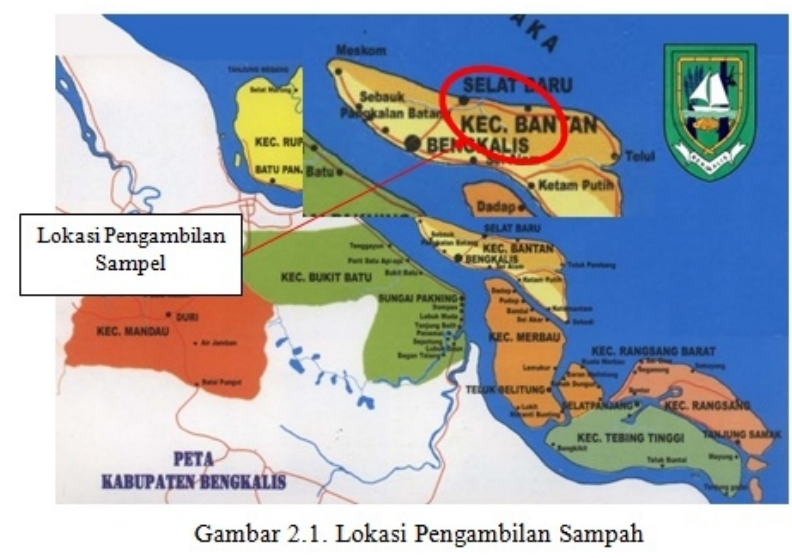

Pelaksanaan penelitian ini dilaksanakan di laboratorium Uji Bahan Politeknik Negeri Bengkalis. Tahapan dalam penelitian ini lebih lengkap dijelaskan pada bagan alir pada gambar 3, adapun tahapan dalam penelitian ini kegiatan sebagai berikut :

1. Pengumpulan material sampah organik dan anorganik, lokasi pengambilan sampah di daerah Kecamatan Bengkalis.

2. Persiapan tungku pembakaran sampah yang terbuat dari drum berkapasitas 200 liter dengan model pembakaran dengan menggunakan pembakaran konvensional. 


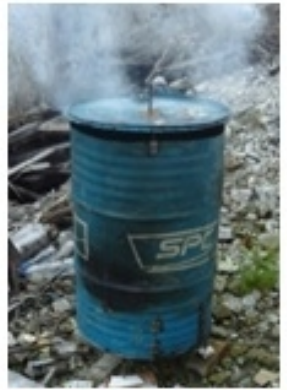

Gambar 2.2. Proses pembakaran sampah

3. Hasil pembakaran sampah akan dikumpulkan dan dilakukan uji saringan, yaitu yang lolos saringan 100 dan 200.

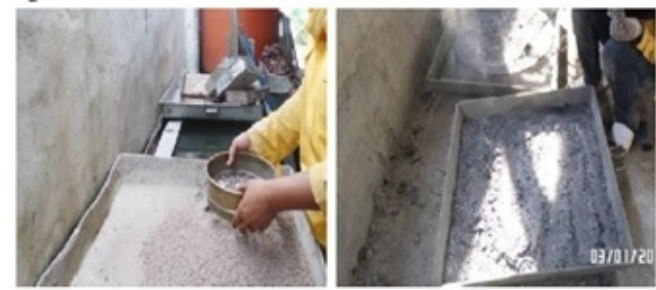

Gambar 2.3. Proses pengumpulan dan penyaringan abu sampah

4. Hasil uji saringan (abu sampah) diambil dan dilakukan proses pengadukan antara semen dengan abu sampah.

5. Merencanakan campuran beton dengan mutu $\mathrm{fc}^{\prime}=10 \mathrm{MPa}$ dan $\mathrm{fc}^{\prime}=20 \mathrm{MPa}$.

6. Pembuatan benda uji beton silinder dengan campuran ekosemen, pasir dan agregat kasar dengan perbandingan kondisi normal yaitu semen, pasir dan agregat kasar. Abu sampah sebagai bahan sustitusi semen, variasi campuran abu sampah untuk menggantikan semen adalah $0 \%, 10 \%, 20 \%$, $30 \%, 40 \%, 50 \%$ terhadap volume. Jumlah benda uji disetiap variasi campuran sebanyak 3 buah benda uji silinder.

7. Perawatan benda uji di lakukan dengan cara perendaman.

8. Kemudian pelaksanaan uji tekan silinder, uji tekan dilakukan pada hari 7, 14 dan 28 hari.

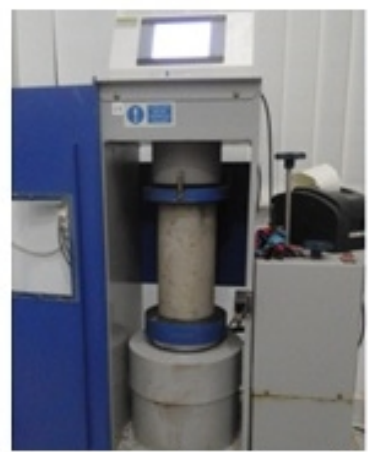

Gambar 2.4. Pengujian kuat tekan beton

Bagan alir penelitian dan analisa data adalah sebagai berikut:

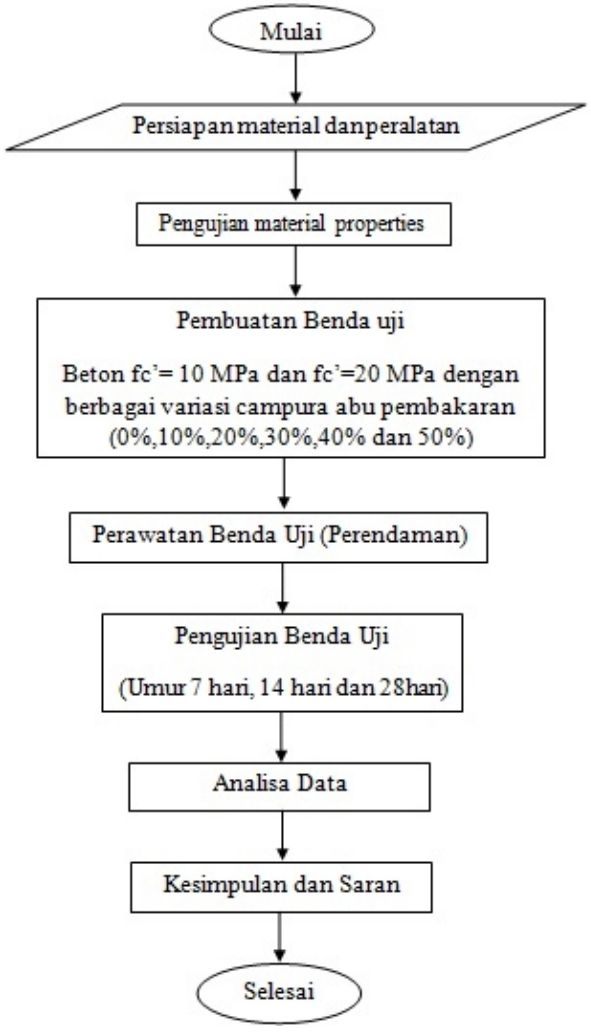

Gambar 2.5. Bagan alir penelitian dan analisa data

\section{HASIL DAN PEMBAHASAN}

Pemeriksaan Material

Hasil pemeriksaan material meliputi pemeriksaan terhadap agregat halus (pasir) dan agregat kasar 
(split), pasir dan split yang digunakan berasal dari Tanjung Balai Karimun.

\begin{tabular}{|c|c|c|}
\hline Nama pemeriksaan & Agregat halus & Agregat kasar \\
\hline Kadar air & $1,76 \%$ & $0,43 \%$ \\
\hline Berat jenis kondisi SSD & 2,578 & 2,613 \\
\hline Berat isi & 2,603 & 2,580 \\
\hline Kandungan lumpur & $1,8 \%$ & $0,83 \%$ \\
\hline Modulus halus butir & 2,641 & 6,983 \\
\hline
\end{tabular}

Dari hasil pemeriksaan dapat disimpulkan, agregat halus dan agregat kasar yang digunakan memenuhi persyaratanuntuk dipakai sebagai bahan penyusun beton. Untuk semen, abu sampah dan air pemeriksaan hanya dilakukan secara visual dan memenuhi syarat untuk bahan pembuatan beton.

\section{Berat Isi Beton}

Pengujian berat isi beton dilakukan pada beton silinder yang telah dirawat dengan perendaman, dari hasil pengujian diperoleh hasil bahwa dengan penggantian abu sampah sebagai perekat dengan variasi campuran, tidak mempengaruhi berat isi beton. Sesuai dengan SNI 03-2847-2002 berat isi beton normal $2.200 \mathrm{~kg} / \mathrm{m} 3-2500 \mathrm{~kg} / \mathrm{m} 3$.

\section{Kuat Tekan Beton}

Pengujian kuat tekan beton dilakukan dengan menggunakan mesin uji tekan beton (compression test) pada umur 7, 14 dan 28 hari dengan perawatan perendaman beton di dalam air. Hasil pengujian dapat dilihat sebagai berikut:

\begin{tabular}{|c|c|c|c|}
\hline \multirow{2}{*}{ Penambahan abu (\%) } & \multicolumn{3}{|c|}{ Kuat tekan beton (MPa) } \\
\hline & 7 hari & 14 hari & 28 hani \\
\hline 0 & 11,39 & 10,46 & 10,19 \\
\hline 10 & 8.48 & 10,62 & 10,25 \\
\hline 20 & 8,14 & 9,17 & 12,76 \\
\hline 30 & 7,71 & 4,80 & 8,53 \\
\hline 40 & 9,20 & 4,54 & 7.62 \\
\hline 50 & 4,89 & 3,87 & 5,97 \\
\hline
\end{tabular}

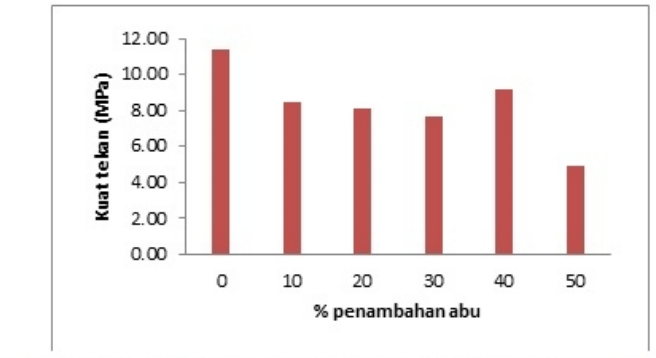

Gambar 3.1. Grafik kuat tekan beton $\mathrm{fc}^{\prime}=10 \mathrm{MPa}$ pada umur 7 hari
Pada Gambar 4 hasil kuat tekan beton umur 7 hari bervariasi, tatapi variasi yang terjadi selisihnya tidak terlalu besar terutama untuk beton yang memiliki kandungan abu sampah, kecuali untuk variasi beton $50 \%$, hal ini terjadi karena kadar semen terkandung didalamnya jumlahnya sangat kecil dibanding variasi beton yang lainnya.

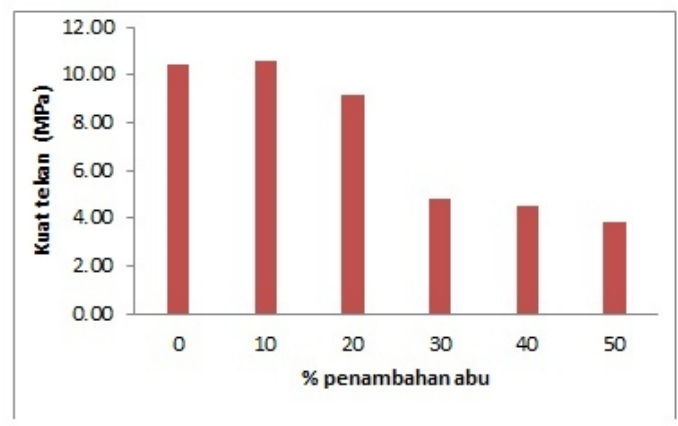

Gambar 3.2. Grafik kuat tekan beton $f^{\prime}=10 \mathrm{MPa}$ pada umur 14 hari

Pada Gambar 5 hasil kuat tekan beton umur 14 hari bervariasi, ada kenderungan semakin banyak persentase abu sampah yang digunakan, maka semakin menurun kuat tekan beton tersebut. Persentase penurunan yang mencolok terjadi pada variasi $20 \%$ dengan $30 \%$, terjadi selisih penurunan sebesar $47,65 \%$.

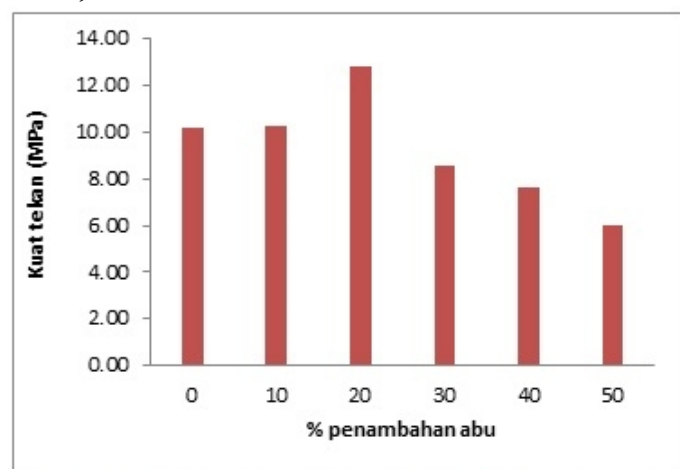

Gambar 3.3. Grafik kuat tekan beton $\mathrm{fc}^{\prime}=10 \mathrm{MPa}$ pada umur 28 hari Pada Gambar 6 dapat dilihat hasil kuat tekan beton umur 28 hari bervariasi, untuk variasi $10 \%$ dan $20 \%$ masih sesuai dengan kuat tekan rencana, sedangkan untuk variasi $30 \%, 40 \%$ dan $50 \%$ semakin banyak persentase abu sampah yang digunakan, maka semakin menurun kuat tekan beton tersebut. Hal ini terjadi disesbkan semakin banyaknya pengurangan semen yang digunakan pada campuran beton tersebut. Dari hasil kuat tekan 
makan variasi beton yang terbaik adalah variasi penambahan abu sampah sebesar $20 \%$.

Untuk hsil pengujian kuat tekan mutu beton $\mathrm{fc}^{\prime}=20 \mathrm{MPa}$ hasil yang diperoleh adalah sebagai berikut:

Tabel 3.3. Pengujian kuat tekan beton $\mathrm{fc}^{\prime}=20 \mathrm{MPa}$

\begin{tabular}{cccc}
\multicolumn{4}{c}{ Tabel 3.3. Pengujian kuat tekan beton $\mathrm{fc}^{\prime}=20 \mathrm{MPa}$} \\
\hline & \multicolumn{3}{c}{ Kuat tekan beton $(\mathrm{MPa})$} \\
\cline { 2 - 4 } Penambahan abu (\%) & 7 hari & 14 hari & 28 har \\
\hline 0 & 10,34 & 11,94 & 20,06 \\
10 & 8,38 & 10,53 & 14,21 \\
20 & 6,18 & 9,57 & 17,29 \\
30 & 6,01 & 7,05 & 15,93 \\
40 & 6,40 & 7,75 & 7,98 \\
50 & 5,22 & 3,95 & 7,13 \\
\hline
\end{tabular}

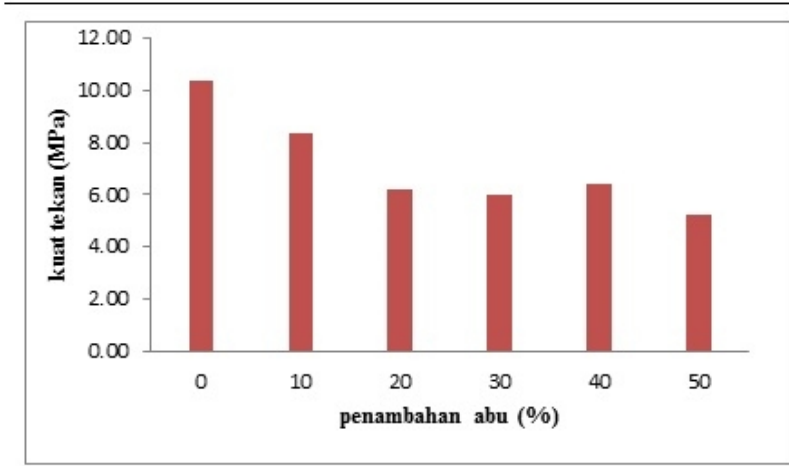

Gambar 3.4. Grafik kuat tekan beton $\mathrm{fc}^{\prime}=20 \mathrm{MPa}$ pada umur 7 hari

Pada Gambar 7 hasil kuat tekan beton $\mathrm{fc}^{\prime}=20$ MPa pada umur 7 hari, untuk beton yang mengandung abu hampir sama, selisihnya tidak terlalu besar, kecuali untuk variasi beton $10 \%$, memiliki kuat tekan yang lebih tinggi dibandingkan dengan beton yang mengandung abu lainnya. hal ini terjadi karena kadar semen terkandung didalamnya jumlahnya lebih besar dibandingkan dengan variasi beton yang mengandung abu lainnya. Sehingga untuk kuat beton normal nilainya lebih tinggi dibandingkan dengan beton yang lain.

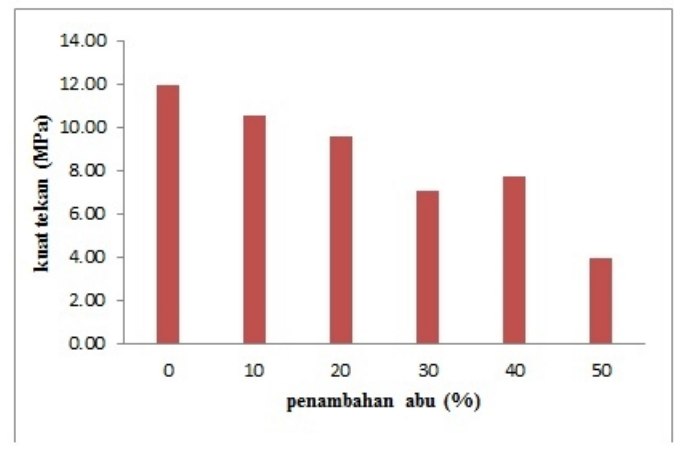

Gambar 3.5. Grafik kuat tekan beton $f c^{\prime}=20 \mathrm{MPa}$ pada umur 14 hari
Pada Gambar 8 hasil kuat tekan beton $\mathrm{fc}^{\prime}=20$ MPa pada umur 14 hari bervariasi, ada kenderungan semakin banyak persentase abu sampah yang digunakan, maka semakin menurun kuat tekan beton tersebut. Hal ini bisa terjadi karena dipengaruhi oleh jumlah semen yang terkandung dalam beton tersebut.

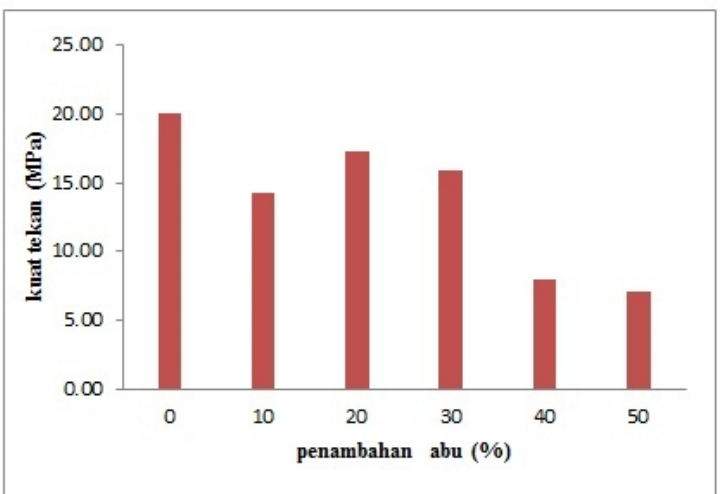

Gambar 3.6. Grafik kuat tekan beton $f^{\prime}=20 \mathrm{MPa}$ pada umur 28 hari

Pada Gambar 9 dapat dilihat hasil kuat tekan beton $\mathrm{fc}^{\prime}=20 \mathrm{MPa}$ pada umur 28 hari untuk kuat tekan beton yang mengandung abu terdapat kuat tekan beton optimum pada variasi penambahan abu sebesar 20\% yaitu 17,29 $\mathrm{MPa}$, memiliki selisih $13,8 \%$ lebih rendah dibandingkan kuat tekan beton normal. Untuk variasi $40 \%$ dan $50 \%$ terjadi penurunan yang sangat signifikan, jika di bandingan dengan kuat tekan beton normal selisih beton yang terjadi sekitaran $65 \%$. Hal ini terjadi disebabkan semakin banyak persentase abu sampah yang digunakan, maka semakin menurun kuat tekan beton tersebut.

Sedangkan untuk hubungan antara kuat tekan beton dan umur beton, dari beberapa variasi campuran yang telah dibuat, terdapat kecendrungan semakin lama umur beton makan semakin bertambah kuat tekan beton tersebut.

\section{KESIMPULAN}

Kesimpulan yang diambil dari penelitian ini adalah sebagai berikut: Berat isi beton dengan variasi penembahan abu sampah tidak berubah, untuk beton mutu $\mathrm{fc}^{\prime}=10 \mathrm{MPa}$ dan beton mutu $\mathrm{fc}$ '= $20 \mathrm{MPa}$. Untuk mutu beton $10 \mathrm{MPa}$, dengan menggantikan semen dengan abu sampah sebanyak 
$20 \%$, mampu meningkatkan kuat tekan beton di bandingkan dengan beton normal. Untuk mutu beton $20 \mathrm{MPa}$, dengan menggantikan semen dengan abu sampah sebanyak 20\% memiliki kuat tekan sebesar 17,29 $\mathrm{MPa}$, nilai kuat tekan terbesar dibanding kuat tekan beton yang mengandung abu, selisih kuat tekan 13,8\% lebih rendah dibandingkan kuat tekan beton normal. Hubungan antara umur beton dengan kuat tekan beton untuk kedua jenis mutu beton, ada kecenderungan semakin bertambah umur beton maka semakin bertambah nilai kuat tekannya.

Saran yang diperlukan pada penelitian ini adalah penelitian selanjutnya bisa dilakukan untuk variasi mutu beton yang lain dan bisa dilakukan dengan penambahan zat additif..

\section{UCAPAN TERIMA KASIH}

Terima kasih kepada semua pihak yang telah membantu penelitian ini terutama Jurusan Teknik Sipil Politeknik Negeri Bengkalis yang telah memfasilitasi penulis.

\section{REFERENSI}

Anonim. 2006. Ecocement: New Recycling Resources Reborn for an Affluent Future.

Frieska Ariesta S dan Dyah Sawitri. (2013). "Studi

Eksperimental Pembuatan Ekosemen dari Abu

Sampah dan Cangkang Kerang sebagai Bahan Alternatif Pengganti Semen"Jurnal Teknik POMITS, Vol. 2, No. 2., Jurusan Teknik Fisika Institut Teknologi Sepuluh November, Surabaya. Idham, M (2014) Pemanfaatan Abu Sisa Pembakaran Sampah sebagai Bahan Stabilisasi Tanah, Penelitian Dosen Pemula, Jurusan Teknik Sipil, Politeknik Negeri Bengkalis.

Neli Susanti. 2009. Pembuatan Ekosemen Dari Abu

Sampah Dan Uji Aplikasinya Untuk Panel

Beton. Tesis. Sekolah Pascasarjana Universitas Sumatera Utara. Medan.

Nelvia Adi Syafpoetri, Monita Olivia, Lita Darmayanti.2012." Pemanfaatan Abu Kulit Kerang (Anadara grandis) Untuk Pembuatan Ekosemen". Tugas Akhir. Jurusan Teknik Sipil Fakultas Teknik Universitas Riau Pekanbaru.
Nunik, G. P. 2016. Pembuatan Ekosemen Berbahan Abu Cangkang Kerang, Abu Sampah Organik, Dan Lumpur Limbah. Skripsi. Program Studi Ilmu dan Teknologi Lingkungan. Universitas Airlangga. Surabaya.

Shinta Marito Siregar.2009." Pemanfaatan Kulit Kerang Dan Resin Epoksi Terhadap Karakteristik Beton Polimer".Tesis.Jurusan Fisika Sekolah Pascasarjana Universitas Sumatera Utara Medan.

Siswanti, N.,D., Nanda, R., dan Anggraini (2009) Pembuatan Ekosemen dari Sampah Organik, Jurnal Teknik Kimia, Vol. 3, No. 2, Jurusan Teknik Kimia UPN Veteran Jawa Timur.

T. Shimoda, S., dan Yokoyama. 2009. Ecocement-a new Portland cement to solve municpal and industrial waste problem, Proc. Of International Congress with Concrete, Dundee.

Wiradarma, L.W. 2007. Pemanfaatan Abu Sampah Padat Perkotaan (Municipal Solid Waste) Kota Mataram Sebagai Alternatif Bahan Stabilisasi Tanah Lempung, Vol. 3, No. 1, pp. 26-37. 